\title{
Impact of Treatment of Intestinal Parasites on the Activity of Ulcerative Colitis
}

\author{
El-Sayed A. Saad ${ }^{1}$, Amr A. Mourad ${ }^{1}$, Ahmad M. Mahmoud ${ }^{1}$, Hala I. Hussien ${ }^{1}$, \\ Soha A. Elhawari ${ }^{1}$, Mohamed H. Emara ${ }^{1}$, Sabah M. A. Mohamed ${ }^{2}$ \\ ${ }^{1}$ Tropical Medicine Departement, Faculty of Medicine,Zagazig University, Egypt \\ ${ }^{2}$ Parasitology Departement,Faulty of Medicine, Zagazig University, Egypt
}

See editorial pages 89-90

Corresponding Author El-Sayed A. Saad

Mobile:

$+201063135898$

E mail:

say_ma2008@yahoo. com

Key words: Ulcerative colitis; intestinal parasites; immunemodulation
Background and study aim: Ulcerative colitis (UC) is common in Western industrialized countries, while it is uncommon in developing countries where helminthic infections are frequent. This study aimed to detect the impact of treatment of intestinal parasites on the activity of UC.

Patients and methods: Twenty patients with UC and intestinal parasitic infection were selected out of 57 patients with UC by 3 successive days of stool analysis and anal swabs. They were randomized into; group I $(n=10)$ received treatment for their intestinal parasitic infection and group II $(n=10)$ did not receive treatment. Patients were evaluated using simple clinical colitis activity (SCCA) index, laboratory investigations and colonoscopy, before and one month after treatment of intestinal parasites in group I, one month from the first visit in group II to evaluate the activity of the disease.

Results: Patients who were treated for intestinal parasites had statisticaly significant deterioration in bowel frequency/day $\quad(p=0.04)$, and bowel

\section{INTRODUCTION}

Ulcerative colitis (UC) is a chronic inflammatory disorder of unknown cause affecting mainly rectum and colon [1].The current hypothesis of its pathogenesis suggests that UC results from an uncontrolled immune response to the normal gut flora [2]. Current treatment relies heavily on corticosteroids and broad spectrum immunosuppressives that have significant side effects [3].The prevalence of UC is not uniform worldwide; being most common in Western industrialized countries and uncommon in developing countries [4]. This suggests that environmental factors (proposed to be loss of frequency/night $(\mathrm{p}=0.038)$.On the other side, the untreated group showed non significant change in all parameters of SCCA index after one month, but overall, their bowel frequency/day, bowel frequency/night and the general condition were significantly better than those of the treated group. There was statistically significant deterioration in hemoglobin $(p=0.049)$, WBC's $(p=0.01)$ in the treated group, while erythrocyte sedimentation rate (ESR) and C-reactive protein (CRP) which remained unchanged in the treated group showed significant improvement in the untreated group in addition to improved hemoglobin levels after one month. WBC's and CRP were significantly lower in the untreated group in comparison with the treated group after one month. The treated group had more severe colonoscopic findings in comparison with the untreated group after one month $(\mathrm{p}=0.02)$.

Conclusion: Treatment of intestinal parasites deteriorates the clinical activity of the ulcerative colitis. helminths) favor the wider spread of $\mathrm{UC}$ in developed countries or protect from UC in less developed countries[5]. Helminths could be beneficial because of their unique capacity to decrease hyper reactive immune responses [6]. In support of this postulate, it was reported that exposure to helminths, in animal models of IBD, could protect or reverse colitis $[7,8]$. There are complex interactions between helminths and their hosts; successful parasite would suppress the host immune response for survival in their human host [9]. Helminths are known to be the most potent Th2-cell inducers in human and experimental models and this impedes the 
devolpment of TH1- cells [10]. However, UC is associated with a modified Th2-cells response [11]. Thus, the response to a helminthic infection may impede inappropriate $\mathrm{Th} 2$ responses, thus provide suppression of UC activity [12]. Helminths induce regulatory $\mathrm{T}$ cells and promote the production of powerful immunomodulatory molecules such as IL-10 and TGF- $\beta$ and this could underlie their broad-spectrum immunosuppression [13]. Also, parasitic immunomodulation involve excretory/secretory products actively exported through secretory pathways and those may diffuse or leak from the parasite stoma [14].

According to hygiene hypothesis failure to develop immunoregulatory pathways and hence increased incidence of $\mathrm{UC}$ is a consequence of diminished exposure to intestinal helminths [15]. So, the aim of the present study was to find out the impact of treatment of intestinal parasites on the activity of UC.

\section{PATIENTS AND METHODS}

This study was conducted at Zagazig University Hospitals, Zagazig, Egypt in the period from March 2011 to February 2013. Out of 57 patients known to have ulcerative colitis (by colonoscopy and histopathology), 20 patients with intestinal parasitic infection were selected after 3 successive days of stool analysis and anal swabs.

Patients were divided into:

Group I: Comprised 10 patients who were diagnosed to have UC and intestinal parasitic infection, they were treated for intestinal parasites; patients who had Entamoeba histolytica received Tinidazole $2 \mathrm{~g} /$ day for two successive days and followed by diloxanide furoate $500 \mathrm{mg}$ t.i.d for 10 days. Patients who had Blastocystis hominis or Giardia lamblia received Tinidazole $2 \mathrm{gm}$ single dose. Patient who had Hymenolepis nana was treated by praziquantel $25 \mathrm{mg} / \mathrm{Kg}$ single dose. Patients who had Ascaris lumbricoides, Enterobius vermicularis, Trichostrongylus or Trichuris trichura received Albendazole $400 \mathrm{mg}$ single dose $[16,17]$. Patients were considered cleared from parasitic infection when no ova or intestinal protozoa were identified in their stool one month later (all were infection free one month after treatment).

Group II: Comprised 10 patients, who were diagnosed to have UC and intestinal parasitic infection, they were not treated for intestinal parasites. The following medications were allowed and continued at the same dose throughout the study for all patients: (1) oral sulfasalazine, mesalamine, or mesalamine derivatives (2) oral prednisone up to $25 \mathrm{mg} /$ day and (3) azathioprine or 6-mercaptopurine.

The study protocol was approved by the Institutional Review Board of the Faculty of Medicine, Zagazig University, and informed consent was obtained from all participants

\section{Exclusion criteria:}

Patients were not enrolled (1) if they had fulminant colitis (2) if they were treated with cyclosporine, methotrexate, or immunomodulatory agents other than azathioprine/6 mercaptopurine in the last 12 weeks (3) if they had other clinically significant diseases that could interfere with protocol compliance or interpretation of the results (4) if they had hypersensitivity to the used antiparasitic drugs.

All patients were subjected to the followings at the beginning of the study and after one month in both treated and untreated groups:

- Full history taking and thorough clinical examination.

- Assessment of Simple Clinical Colitis Activity Index (SCCA) which was designed and validated by Walmsley et al. [18].

- Laboratory investigations; Complete blood count (CBC), erythrocyte sedimentation rate (ESR) and C-reactive protein (CRP).

- Stool analysis with different microscopic examinations and anal swabs were performed for detection of any helminthic eggs and intestinal protozoa (cysts or trophozoites).

- Colonoscopy to evaluate the activity of the disease. Endoscopic grading (scale of $0-3$ ): $0=$ normal, $1=$ mild friability, $2=$ moderate friability, $3=$ exudation and spontaneous hemorrhage [19].

\section{Statistical Analysis:}

Data were analyzed with SPSS version 17 (statistical package for the Social Science, Chicago, IL). Qualitative data were expressed as number and percentage and were analyzed by Chi square $\left(\mathrm{X}^{2}\right)$ test for unpaired data. Fisher's Exact was recommended when expected value is less than 5. While Wilcoxon test was used to 
analyze qualitative paired data. Quantitative data were expressed as mean \pm standard deviation (SD) and were analyzed by independent $t$ test for unpaired data. Paired quantitative data were analyzed by paired $t$ test. P-value was considered significant if $<0.05$ and highly significant if $<0.001$.

\section{RESULTS}

Characteristics of the patients were comparable in the two groups including types of isolated parasites (Table 1). Both groups showed non statistically significant difference in their base line data as regard parameters of simple clinical colitis activity (SCCA) index, laboratory tests and colonoscopic findings apart from significantly elevated ESR in the untreated group $(\mathrm{p}=0.02)$ (data not shown).

Patients who were treated for intestinal parasites had statisticaly significant deterioration in bowel frequency/day, and bowel frequency/night compared with their baseline data. On the other side, the untreated group showed non significant change in all parameters of SCCA index after one month in comparison with their base line data, but, their bowel frequency/day, bowel frequency/night and the general condition were significantly better than those of the treated group (Table 2, 3).

There was statistically significant deterioration in RBC's, MCV, hemoglobin, WBC's in the treated group, while ESR and CRP which remained unchanged in treated group showed significant improvement in the untreated group in addition to improved hemoglobin levels after one month. Finally, WBC's and CRP were significantly lower in the untreated group in comparison with the treated group after one month (Table 4,5).

There was statistically significant increased friability, exudation and spontaneous hemorrhage among the treated group without significant change in colonoscopic findings among the untreated group, the treated group had more severe colonoscopic findings in comparison with the untreated group after one month (Table 6,7).

Table 1: Characteristics of the patients including the isolated parasites.

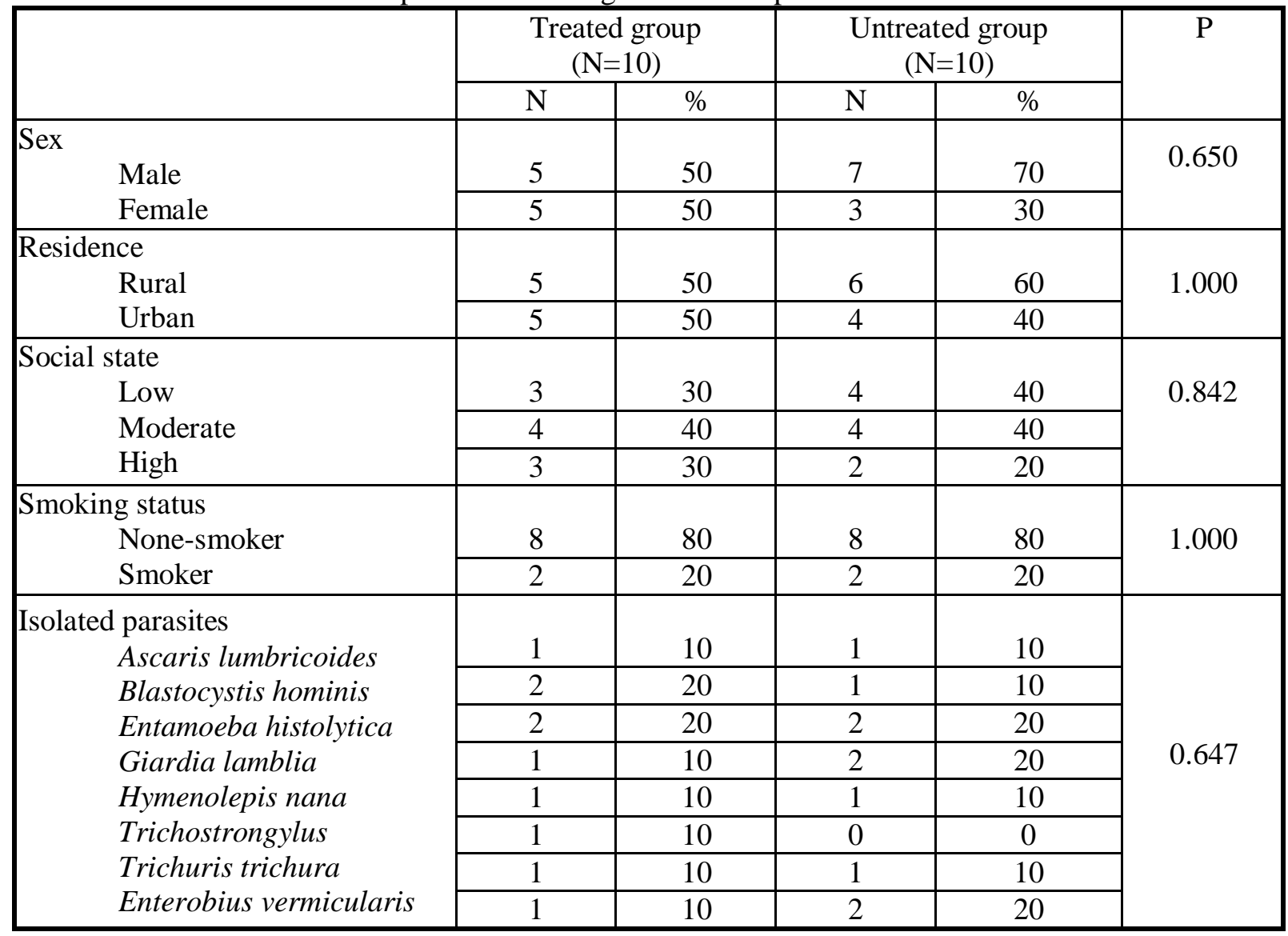


Table 2: Changes in the parameters of simple clinical colitis activity index one month after treatment in treated group versus changes in the parameters of untreated group after one month.

\begin{tabular}{|c|c|c|c|c|c|c|c|c|c|c|c|}
\hline \multirow{3}{*}{\multicolumn{2}{|c|}{ SCCA index parameters }} & \multicolumn{4}{|c|}{$\begin{array}{l}\text { Treated group } \\
\quad(\mathrm{N}=10)\end{array}$} & \multirow[t]{3}{*}{$\mathrm{P}$} & \multicolumn{4}{|c|}{$\begin{array}{l}\text { Untreated group } \\
\qquad(\mathrm{N}=10)\end{array}$} & \multirow[t]{3}{*}{$\mathrm{P}$} \\
\hline & & \multicolumn{2}{|c|}{$\begin{array}{l}\text { Before } \\
\text { treatment }\end{array}$} & \multicolumn{2}{|c|}{$\begin{array}{l}\text { After } \\
\text { treatment }\end{array}$} & & \multicolumn{2}{|c|}{\begin{tabular}{|l} 
Base line \\
data
\end{tabular}} & \multicolumn{2}{|c|}{$\begin{array}{l}\text { After one } \\
\text { month }\end{array}$} & \\
\hline & & $\mathrm{N}$ & $\%$ & $\mathrm{~N}$ & $\%$ & & $\mathrm{~N}$ & $\%$ & $\mathrm{~N}$ & $\%$ & \\
\hline \multirow{4}{*}{$\begin{array}{c}\text { Bowel } \\
\text { frequency/day }\end{array}$} & $1-3$ & 5 & 50 & 3 & 30 & \multirow{4}{*}{0.04} & 6 & 60 & 7 & 70 & \multirow{4}{*}{0.15} \\
\hline & $4-6$ & 4 & 40 & 1 & 10 & & 3 & 30 & 3 & 30 & \\
\hline & $7-9$ & 1 & 10 & 3 & 30 & & 1 & 10 & 0 & 0 & \\
\hline & $>9$ & 0 & 0 & 3 & 30 & & 0 & 0 & 0 & 0 & \\
\hline \multirow{3}{*}{$\begin{array}{c}\text { Bowel } \\
\text { frequency/night }\end{array}$} & 0 & 3 & 30 & 0 & 0 & \multirow{3}{*}{0.03} & 2 & 20 & 4 & 40 & \multirow{3}{*}{0.15} \\
\hline & $1-3$ & 6 & 60 & 5 & 50 & & 8 & 80 & 6 & 60 & \\
\hline & $4-6$ & 1 & 10 & 5 & 50 & & 0 & 0 & 0 & 0 & \\
\hline \multirow{4}{*}{$\begin{array}{l}\text { Urgency of } \\
\text { defecation }\end{array}$} & No & 4 & 40 & 1 & 10 & \multirow{4}{*}{0.1} & 2 & 20 & 4 & 40 & \multirow{4}{*}{0.1} \\
\hline & Hurry & 4 & 40 & 5 & 50 & & 5 & 50 & 5 & 50 & \\
\hline & Immediately & 1 & 10 & 1 & 10 & & 1 & 10 & 0 & 0 & \\
\hline & Incontinence & 1 & 10 & 3 & 30 & & 2 & 20 & 1 & 10 & \\
\hline \multirow{4}{*}{ Blood in stool } & No & 3 & 30 & 0 & 0 & \multirow{4}{*}{0.13} & 2 & 20 & 3 & 30 & \multirow{4}{*}{0.18} \\
\hline & Trace & 5 & 50 & 4 & 40 & & 5 & 50 & 6 & 60 & \\
\hline & $\begin{array}{l}\text { Occasionally } \\
\text { frank }\end{array}$ & 1 & 10 & 3 & 30 & & 3 & 30 & 1 & 10 & \\
\hline & Usually frank & 1 & 10 & 3 & 30 & & 0 & 0 & 0 & 0 & \\
\hline \multirow{4}{*}{$\begin{array}{l}\text { General well- } \\
\text { being }\end{array}$} & Very well & 3 & 30 & 1 & 10 & \multirow{4}{*}{0.05} & 3 & 30 & 7 & 70 & \multirow{4}{*}{0.09} \\
\hline & $\begin{array}{c}\text { Slightly below } \\
\text { normal }\end{array}$ & 5 & 50 & 4 & 40 & & 4 & 40 & 1 & 10 & \\
\hline & Poor & 2 & 20 & 3 & 30 & & 3 & 30 & 2 & 20 & \\
\hline & Very poor & 0 & 0 & 2 & 20 & & 0 & 0 & 0 & 0 & \\
\hline \multirow{3}{*}{$\begin{array}{l}\text { Extra-colonic } \\
\text { features }\end{array}$} & Non & 8 & 80 & 6 & 60 & \multirow{3}{*}{0.18} & 6 & 60 & 6 & 60 & \multirow{3}{*}{0.56} \\
\hline & One & 2 & 20 & 3 & 30 & & 3 & 30 & 4 & 40 & \\
\hline & Two & 0 & 0 & 1 & 10 & & 1 & 10 & 0 & 0 & \\
\hline
\end{tabular}


Table 3: Difference between treated group and untreated group after one month as regard the parameters of simple clinical colitis activity index.

\begin{tabular}{|c|c|c|c|c|c|c|}
\hline \multirow{2}{*}{\multicolumn{2}{|c|}{ SCCA index parameters }} & \multicolumn{2}{|c|}{$\begin{array}{c}\text { Treated group } \\
(\mathrm{N}=10)\end{array}$} & \multicolumn{2}{|c|}{$\begin{array}{l}\text { Untreated group } \\
(\mathrm{N}=10)\end{array}$} & \multirow[t]{2}{*}{$\mathrm{P}$} \\
\hline & & $\mathrm{N}$ & $\%$ & $\mathrm{~N}$ & $\%$ & \\
\hline \multirow{4}{*}{$\begin{array}{c}\text { Bowel frequency/ } \\
\text { Day }\end{array}$} & $1-3$ & 3 & 30 & 7 & 70 & \multirow{4}{*}{0.04} \\
\hline & $4-6$ & 1 & 10 & 3 & 30 & \\
\hline & $7-9$ & 3 & 30 & 0 & 0 & \\
\hline & $>9$ & 3 & 30 & 0 & 0 & \\
\hline \multirow{3}{*}{$\begin{array}{c}\text { Bowel frequency/ } \\
\text { Night }\end{array}$} & 0 & 0 & 0 & 4 & 40 & \multirow{3}{*}{0.01} \\
\hline & $1-3$ & 5 & 50 & 6 & 60 & \\
\hline & $4-6$ & 5 & 50 & 0 & 0 & \\
\hline \multirow{4}{*}{$\begin{array}{l}\text { Urgency of } \\
\text { defecation }\end{array}$} & Non & 1 & 10 & 4 & 40 & \multirow{4}{*}{0.3} \\
\hline & Hurry & 5 & 50 & 5 & 50 & \\
\hline & Immediately & 1 & 10 & 0 & 0 & \\
\hline & Incontinence & 3 & 30 & 1 & 10 & \\
\hline \multirow{4}{*}{ Blood in stool } & Non & 0 & 0 & 3 & 30 & \multirow{4}{*}{0.06} \\
\hline & Trace & 4 & 40 & 6 & 60 & \\
\hline & Occasionally frank & 3 & 30 & 1 & 10 & \\
\hline & Usually frank & 3 & 30 & 0 & 0 & \\
\hline \multirow{4}{*}{$\begin{array}{l}\text { General well- } \\
\text { being }\end{array}$} & Very well & 1 & 10 & 7 & 70 & \multirow{4}{*}{0.037} \\
\hline & Slightly below normal & 4 & 40 & 1 & 10 & \\
\hline & Poor & 3 & 30 & 2 & 20 & \\
\hline & Very poor & 2 & 20 & 0 & 0 & \\
\hline \multirow{3}{*}{$\begin{array}{l}\text { Extra-colonic } \\
\text { features }\end{array}$} & Non & 6 & 60 & 6 & 60 & \multirow{3}{*}{0.565} \\
\hline & One & 3 & 30 & 4 & 40 & \\
\hline & Two & 1 & 10 & 0 & 0 & \\
\hline
\end{tabular}

Table 4: Changes in laboratory parameters one month after treatment in treated group versus changes in laboratory parameters in untreated group after one month

\begin{tabular}{|c|c|c|c|c|c|c|}
\hline \multirow[t]{3}{*}{$\begin{array}{l}\text { Laboratory } \\
\text { parameters }\end{array}$} & \multicolumn{2}{|c|}{$\begin{array}{l}\text { Treated group } \\
(\mathrm{N}=10)\end{array}$} & \multirow{3}{*}{$\mathrm{P}$} & \multicolumn{2}{|c|}{$\begin{array}{c}\text { Untreated group } \\
(\mathrm{N}=10)\end{array}$} & \multirow{3}{*}{$\mathrm{P}$} \\
\hline & Before treatment & $\begin{array}{c}\text { After } \\
\text { treatment }\end{array}$ & & Base line data & $\begin{array}{l}\text { After one } \\
\text { month }\end{array}$ & \\
\hline & $\mathrm{X} \pm \mathrm{SD}$ & $\mathrm{X} \pm \mathrm{SD}$ & & $\mathrm{X} \pm \mathrm{SD}$ & $\mathrm{X} \pm \mathrm{SD}$ & \\
\hline $\mathrm{RBC}$ 's $\times 10^{6} / \mathrm{mm}^{3}$ & $4.5 \pm 0.2$ & $4.0 \pm 0.3$ & 0.01 & $4.3 \pm 0.4$ & $4.4 \pm 0.4$ & 0.25 \\
\hline $\mathrm{MCV} \quad \mathrm{fl}$ & $84.0 \pm 9.2$ & $79.9 \pm 8.9$ & 0.02 & $82.5 \pm 8.0$ & $83.5 \pm 7.1$ & 0.22 \\
\hline $\begin{array}{l}\text { Haemoglobin } \\
(\mathrm{gm} / \mathrm{dl})\end{array}$ & $12.2 \pm 2$ & $10.9 \pm 1.2$ & 0.04 & $11.4 \pm 1.9$ & $11.7 \pm 1.6$ & 0.02 \\
\hline WBC's $\times 10^{3} / \mathrm{mm}^{3}$ & $7.5 \pm 2.2$ & $11.0 \pm 3.0$ & 0.01 & $7.1 \pm 2.2$ & $6.3 \pm 1.4$ & 0.07 \\
\hline $\begin{array}{l}\text { Platelets } \times 10^{3} / \\
\mathrm{mm}^{3}\end{array}$ & $359.6 \pm 98.3$ & $378.5 \pm 99.3$ & 0.56 & $401.7 \pm 49.5$ & $395.4 \pm 48$ & 0.06 \\
\hline $\operatorname{ESR}(\mathrm{mm})$ & $25.1 \pm 13.6$ & $33.9 \pm 16.1$ & 0.18 & $42.6 \pm 16.4$ & $36.7 \pm 12.6$ & 0.01 \\
\hline $\mathrm{CRP}(\mathrm{mg} / \mathrm{dl})$ & $23.2 \pm 12.3$ & $34.9 \pm 7.9$ & 0.07 & $23.6 \pm 7.6$ & $19.6 \pm 7.9$ & $<0.001$ \\
\hline
\end{tabular}


Table 5: Difference between treated group and untreated group after one month as regard laboratory parameters

\begin{tabular}{|l|c|c|c|}
\hline \multirow{2}{*}{ Laboratory parameters } & $\begin{array}{c}\text { Treated group } \\
(\mathrm{N}=10)\end{array}$ & $\begin{array}{c}\text { Untreated group } \\
(\mathrm{N}=10)\end{array}$ & \multirow{2}{*}{$\mathrm{P}$} \\
\cline { 2 - 3 } & $\mathrm{X} \pm \mathrm{SD}$ & $\mathrm{X} \pm \mathrm{SD}$ & \\
\hline RBC's $\left(\mathrm{x} 10^{6}\right)$ & $4.0 \pm 0.3$ & $4.4 \pm 0.4$ & 0.047 \\
\hline MCV fl & $79.9 \pm 8.9$ & $83.5 \pm 7.1$ & 0.33 \\
\hline Haemoglobin gm/dl & $10.9 \pm 1.2$ & $11.7 \pm 1.6$ & 0.23 \\
\hline WBC's $\left(\mathrm{x} 10^{3}\right)$ & $11.0 \pm 3.0$ & $6.3 \pm 1.4$ & $<0.001$ \\
\hline Platelets $\left(\mathrm{x} 10^{3}\right)$ & $378.5 \pm 99.3$ & $395.4 \pm 48$ & 0.63 \\
\hline ESR $(\mathrm{mm})$ & $33.9 \pm 16.1$ & $36.7 \pm 12.6$ & 0.67 \\
\hline $\mathrm{CRP}(\mathrm{mg} / \mathrm{dl})$ & $34.9 \pm 7.9$ & $19.6 \pm 7.9$ & $<0.001$ \\
\hline
\end{tabular}

Table 6: Changes in colonoscopic findings one month after treatment in treated versus changes in colonoscopic findings in untreated group after one month

\begin{tabular}{|c|c|c|c|c|c|c|c|c|c|c|}
\hline \multirow{3}{*}{ Colonoscopic findings } & \multicolumn{4}{|c|}{$\begin{array}{l}\text { Treated group } \\
\quad(\mathrm{N}=10)\end{array}$} & \multirow{3}{*}{$\mathrm{P}$} & \multicolumn{4}{|c|}{$\begin{array}{c}\text { Untreated group } \\
(\mathrm{N}=10)\end{array}$} & \multirow{3}{*}{$\mathrm{P}$} \\
\hline & \multicolumn{2}{|c|}{$\begin{array}{l}\begin{array}{l}\text { Before } \\
\text { treatment }\end{array} \\
\end{array}$} & \multicolumn{2}{|c|}{\begin{tabular}{|l|l} 
After \\
treatment
\end{tabular}} & & \multicolumn{2}{|c|}{$\begin{array}{l}\text { Base line } \\
\text { data }\end{array}$} & \multicolumn{2}{|c|}{$\begin{array}{l}\text { After one } \\
\text { month }\end{array}$} & \\
\hline & $\mathrm{N}$ & $\%$ & $\mathrm{~N}$ & $\%$ & & $\begin{array}{l}\mathrm{N} \\
\end{array}$ & $\%$ & $\mathrm{~N}$ & $\%$ & \\
\hline Normal & 3 & 30 & 0 & 0 & \multirow{4}{*}{0.03} & 2 & 20 & 5 & 50 & \multirow{4}{*}{0.06} \\
\hline Mild friability & 4 & 40 & 3 & 30 & & 6 & 60 & 4 & 40 & \\
\hline Moderate friability & 3 & 30 & 5 & 50 & & 1 & 10 & 1 & 10 & \\
\hline $\begin{array}{l}\text { Exudation and spontaneous } \\
\text { hemorrhage }\end{array}$ & 0 & 0 & 2 & 20 & & 1 & 10 & 0 & 0 & \\
\hline
\end{tabular}

Table 7: Difference between treated group and untreated group after one month as regard colonoscopic findings

\begin{tabular}{|l|c|c|c|c|c|}
\hline \multirow{2}{*}{\multicolumn{1}{|c|}{ Colonoscopic findings }} & \multicolumn{2}{|c|}{$\begin{array}{c}\text { Treated group } \\
(\mathrm{N}=10)\end{array}$} & \multicolumn{2}{c|}{$\begin{array}{c}\text { Untreated group } \\
(\mathrm{N}=10)\end{array}$} & \multirow{2}{*}{$\mathrm{P}$} \\
\cline { 2 - 5 } & $\mathrm{N}$ & $\%$ & $\mathrm{~N}$ & $\%$ & \\
\hline Normal & 0 & 0 & 5 & 50 & \\
\hline Mild friability & 3 & 30 & 4 & 40 & \multirow{2}{*}{0.02} \\
\hline Moderate friability & 5 & 50 & 1 & 10 & \\
\hline Exudation and spontaneous hemorrhage & 2 & 20 & 0 & 0 & \\
\hline
\end{tabular}

\section{DISCUSSION}

Hygiene hypothesis suggests that failure to develop immunoregulatory pathways and hence increased incidence of $\mathrm{UC}$ is a consequence of diminished exposure to intestinal helminths [15]. In the current study, a suggested real life scenario, the impact of helminths infection in the suppression of IBD activity is elucidated.

In this study, it was documented that patients treated for intestinal parasites had significant deterioration of bowel frequency/day and bowel frequency/night compared to their baseline values. In concordance with this observation, Buning et al. [20]; reported a girl whose UC worsened after eradication of Enterobius vermicularis. In their study, a 12-year old girl was admitted with sporadically bloody stools, treated with rectal meslazine that was ineffective. Colonoscopy revealed discrete unspecific proctitis and numerous worms throughout the colon. Microscopically, faint characteristic signs of UC were reported as well as worm eggs detected in the lamina propria. Adult forms of Enterobius vermicularis and corresponding eggs were identified microbiologically. She was considered a latent UC that was rendered symptomatic due to worm invasion. Administered add-on treatment with Pyrantel pamoate made diarrhea subside. Six months later, the patient was admitted again suffering from abdominal pain and bloody diarrhea. 
Colonoscopy revealed severe UC of the whole colon without detection of any worm. Histopathology, confirmed UC. The patient received steroid therapy and recovered. Consequently, it was suggested that treatment of intestinal parasites deteriorated UC in this patient.

In the present study, patients who were treated for intestinal parasites had non-significant deterioration in urgency of defecation, blood in stool, general well being and extracolonic features compared to their baseline data. Buning et al. [20]; reported significant bleeding per rectum in their case report, a condition that was not encountered in the present study. This may be attributed to the short duration of follow up in the current study; (one month versus 6 months in their case).

In this study, it was found that patients who were not treated for intestinal parasites had statistically non-significant change as regard bowel frequency/day, bowel frequency/night, urgency of defecation, blood in stool, general well being and extra colonic features compared to their baseline data. Although this, there was statistically non-significant difference between both groups as regard SCCA index parameters before treatment of intestinal parasites, while one month after treatment there was statistically significant higher bowel frequency/day, bowel frequency /night and poor general condition among patients of group I in comparison with group II. Such deteriorations may be attributed to lack of immunomodulatory and nonimmunological mechanisms, secondary to loss of helminths that could interfere with the inappropriate and destructive immune response in UC [6]. These findings point to the potential usefulness of the presence of intestinal parasites for patients with UC.

This study shows that patients who were treated for intestinal parasites showed statistically significant deterioration of WBC's count, hemoglobin as compared to their baseline values. While patients who were not treated for intestinal parasites showed statistically significant improvement one month later as regard hemoglobin. Such changes of the activity indices reflect increased UC activity after eradication of intestinal parasites.

At the beginning of the study there was significant increased ESR in untreated group which showed statistically significant improvement, as well as CRP, one month later when compared to their baseline values. While there was statistically non significant deterioration of ESR and CRP among patients of treated group when compared to their baseline values. This may be attributed to short duration of follow up or the difference in the duration or load of infection among both groups [21].

In the current study, there was statistically nonsignificant difference between both groups before treatment of intestinal parasites as regard colonoscopy features; patients who were treated for intestinal parasites had statistically significant deterioration of colonoscopic findings as compared to their baseline values. Buning et al. [20]; in their case report have documented severe pancolitis after eradication of Enterobius vermicularis. On the other hand patients who were not treated for intestinal parasites had nonsignificant difference one month later as regard colonoscopic findings, when compared to their baseline values. These results suggest that eradication of intestinal parasites deteriorate the colonoscopic grade in patients with UC.

From the present study, although subgroups (helminths versus protozoa) were too small for statistical comparison, it can be concluded that intestinal parasites ameliorate the activity of UC. These results confirmed the results of Summers et al. [22]; who reported that Trichuris suis ova therapy administered every other week induces improvement in patients with active UC. Trichuris suis is considered as a therapeutic option with favorable characteristics and outcome [23]. It is not a natural human parasite but it has been shown experimentally to colonise humans briefly without causing disease [24]. Helminths exert multiple mechanisms in their host including induction of Th2 immune responses and directing immune responses away from Th1/Th17. They also induce production of IL-4, IL-10 and IL13 and inhibit IL-12 and TNF$\alpha$ release. Perhaps the most important mechanism against immune mediated injury is promotion of regulatory circuits [25-26]. Eukaryotic protozoan pathogens also have evolved to evade immune defenses responses of their host, but through entirely different mechanisms. Sacks and Sher [27] described how protozoa can avoid immune attack by using humoral effector mechanisms through resistance of complement lysis, resistance to intracellular lysosomal enzymes and toxic metabolites and modifying antigen-presenting and 
immunoregulatory functions of dendritic cells. This makes their ability to affect destructive immune and inflammatory processes possible.

Our study has its limitations. Firstly, the small number of patients recruited, but this may reflect the declining prevalence of parasitic infestation in our community due to many reasons including health education and proper sanitary environment. Also, this supports the hypothesis of low incidence of UC with active intestinal parasitic infection. Secondly, inclusion of protozoa in the final analysis, protozoa may have a different immunological response than helminths. This is mainly due to geographical distribution, our community is a subtropical zone and protozoa are highly prevalent in these communities and hence commonly encountered in daily medical practice and those patients may seek medical advice and sometimes go to self medication by the anti-parasitic drugs. Both groups involved in this study had no statistical difference at the beginning of the study, so the tested variable here is the treatment, and not the type of organism. However, analysis of the impact of different types of intestinal parasites and their treatment is an interesting issue for research in a future study with larger number of patients.

Consequently, further trials that involve longer duration of follow up, histopathological and molecular studies to evaluate the activity of UC at different levels and to determine the critical duration and load of infection which affect the activity of UC are warranted.

\section{CONCLUSION}

It can be recommended not to treat tolerated intestinal helminths in ulcerative colitis patients as they may be beneficial because of their unique capacity to decrease hyper reactive immune responses.

\section{Funding: Non.}

Conflicts of interest: The authors declare that there is no conflict of interest.

Ethical approval: Was granted by the Institutional Review Board and informed consent was obtained from each patient prior to inclusion in the study.

\section{REFERENCES}

1. Bouma G, Strober W. The immunological and genetic basis of inflammatory bowel disease. Nat. Rev. Immunol. 2003; 3: 521-533.
2. Strober W, Fuss I, Mannon P. The fundamental basis of inflammatory bowel disease. J Clin Invest. 2007; 117: 514-521.

3. Siegel CA, Hur C, Korzenik R, Gazelle GS, Sands BE. Risks and benefits of infliximab for the treatment of Crohn's disease. Clin Gastroenterol Hepatol 2006; 8: 1017-1024.

4. Loftus EV. Clinical epidemiology of inflammatory bowel disease: incidence, prevalence, and environmental influences. Gastroenterol 2004; 126: 1504-1517.

5. Elliott DE, Urban JF, Argo CK, Weinstock JV. Does the failure to acquire helminthic parasites predispose to Crohn's disease? FASEB Journal 2000; 14: 1848-1855.

6. Maizels RM, Yazdanbakhsh M. Regulation of the immune response by helminth parasites: cellular and molecular mechanisms. Nat Rev Immunol 2003; 3:733-743.

7. Elliott D, Li J, Blum A, Metwali A, Qadir K, Urban J F, Weinstock JV. Exposure to Schistosome eggs protects mice from TNBS induced colitis. Am J Physiol 2003; 284: 385391.

8. Elliott DE, Setiawan T, Metwali A, Blum A, Urban JF, Weinstock JV. Heligmosomoides polygyrus inhibits established colitis in IL-10deficient mice. Eur J Immunol 2004; 34: 26902698.

9. Riffkin M, Seow HF, Jackson D, Brown L, Wood P. Defence against the immune barrage: helminth survival strategies. Immunol Cell Biol 1996; 74: 564-574.

10. Maizels RM, Bundy DA, Selkirk ME, Smith DF, Anderson RM. Immunological modulation and evasion by helminth parasites in human populations. Nature 1993; 365: 797-805.

11. Raddatz D, Bockemuhl M, Ramadori G. Quantitative measurement of cytokine mRNA in inflammatory bowel disease: relation to clinical and endoscopic activity and outcome. Eur $J$ Gastroenterol Hepatol 2005; 17: 547-557.

12. Greene BM, Fanning MM, Ellner JJ. Nonspecific suppression of antigen-induced lymphocyte blastogenesis in Onchocerca volvulus infection in man. Clin Exp Immunol. 1983; 52: 259-265.

13. Doetze A, Satoguina J, Burchard G, Rau T, Loliger C, Fleischer B et al. antigen specific cellular hyporesponsiveness in a chronic human helminth infection is mediated by Th3/Tr1-type cytokines IL-10 and TGF- $\beta$ but not by a Th1 to Th2 shift. Int. Immunol 2000; 12: 623-630.

14. Hewitson JP, Grainger J, Maizels RM. Helminth immunoregulation: the role of parasite secreted proteins in modulating host immunity. Mol. Biochem. Parasitol. 2009; 167: 1-11. 
15. Rook GA. The hygiene hypothesis and the increasing prevalence of chronic inflammatory disorders. Transactions of the Royal Society of tropical Medicine and Hygiene. 2007; 101: 10721074.

16. Brooker S, Bandy D. Soil transmitted helminths. In Manson's tropical medicine, 22nd Edition, Edited by Cook, G.L. and Zumla, A.I 2009: 1515.

17. Farthiny M, Cellavos A, Kelly P. Intestinal protozoa. In Manson's tropical medicine, 22nd Edition, Edited by Cook, G.L. and Zumla, A.I 2009: 1375.

18. Walmsley R.S, Ayres RC, Pounder RE, Allan RN. A simple clinical colitis activity index. Gut 1998; 43: 29-32.

19. Sutherland L, Martin F, Greer S, Robinson M, Greenberger N, Saibil F, et al. 5-amino salicylicacid enema in the treatment of distal ulcerative colitis, proctosigmoiditis, and proctitis. Gastroenterol 1987; 92: 1894-1898.

20. Buning J, Homann N, von Smolinski D, Borcherding F, Noack F, Stolte $M$, et al. Helminths as governors of inflammatory bowel disease. Gut 2008; 57: 1182-1183.

21. Yazdanbakhsh M, van den Biggelaar A, Maizels RM. Th2 responses without atopy: immunoregulation in chronic helminth infections and reduced allergic disease. Trends Immunol 2001; 22: 372-377.

22. Summers RW, Elliott DE, Urban JF, Thompson RA, Weinstock JV. Trichuris suis therapy for active ulcerative colitis: a randomized controlled trail .Gastroenterol 2005; 4: 825-832.
23. Beer RJ. The relationship between Trichuris trichiura of man and Trichuris suis of the pig. Research in Veterinary Science 1976; 20: 47-54.

24. Summers RW, Elliott DE, Qadir K, Urban JF, Thompson RA, Weinstock JV, et al. Trichuris suis seems to be safe and possibly effective in the treatment of inflammatory bowel disease. Am. $J$ Gastroenterol 2003; 98: 2034-2041.

25. Elliott DE, Weinstock JV. Helminth-host immunological interactions: prevention and control of immune-mediated diseases. Ann. N.Y. Acad. Sci. 2012; 1247:83-96.

26. McSorley HJ, Hewitson, JP, Maizels RM. Immunomodulation by helminth parasites: Defining mechanisms and mediators. Int J Parasit 2013; 43:301-310.

27. Sacks D, Sher A. Review: Evasion of innate immunity by parasitic protozoa. Nature Immunol 2002; 3:1041-47.

Peer reviewer: Robert W. Summers Department of Internal Medicine, Division of Gastroenterology and Hepatology, University of Iowa Carver College of Medicine, USA; Mohamed N El-Khashab Professor of Tropical Medicine and HepatoGastroenterology, Faculty of Medicine , Zagazig Universty , Egypt.

Editor : Tarik Zaher ; Professor of Tropical Medicine, Faculty of Medicine , Zagazig Universty, Egypt. 